\title{
Diversity, Population Structure and Regeneration Status of Woody Species in Dry Woodlands Adjacent to Molapo Farms in Northern Botswana
}

\author{
John Neelo ${ }^{1}$, Demel Teketay ${ }^{2 *}$, Wellington Masamba ${ }^{1}$, Keotshephile Kashe ${ }^{1}$ \\ ${ }^{1}$ Okavango Research Institute, University of Botswana, Maun, Botswana \\ ${ }^{2}$ Department of Crop Science and Production, Botswana College of Agriculture, Gaborone, Botswana \\ Email: "dteketay@bca.bw, ${ }^{*}$ dteketay@yahoo.com
}

Received July $27^{\text {th }}, 2013$; revised August $30^{\text {th }}, 2013$; accepted September $12^{\text {th }}, 2013$

Copyright (C) 2013 John Neelo et al. This is an open access article distributed under the Creative Commons Attribution License, which permits unrestricted use, distribution, and reproduction in any medium, provided the original work is properly cited.

\begin{abstract}
The diversity, population structure and regeneration status of woody species were studied at Xobe and Shorobe Villages in northern Botswana. A total of 130 and 111 quadrats of $20 \times 20 \mathrm{~m}$ size were laid down at $50 \mathrm{~m}$ intervals along parallel line transects at Xobe and Shorobe, respectively. A total of 46 woody species, 27 from Xobe and 41 from Shorobe were recorded. Of the 46 woody species, only 22 were recorded at both sites. Ten genera and six families were found only in Shorobe while one genus and one family were found only in Xobe. The diversity and evenness of woody species were 1.5 and 0.5 in Xobe, respectively, and 2.18 and 0.6 in Shorobe, respectively. The similarities of woody species in terms of richness of species, genera and families at the two sites were about $50 \%, 54 \%$ and $56 \%$, respectively. The mean densities of woody species were $2745.7 \pm 1.35$ and $4269.7 \pm 36$ individuals $^{-1}{ }^{-1}$ at Xobe and Shorobe, respectively. Despite differences in absolute numbers, the total mean densities of woody species at both sites did not exhibit significant $(P=0.35)$ differences. At both sites, woody species were dominated by individuals of only a few species, which also exhibited the highest values of important value index. The population structure patterns of the woody species were categorized into five groups. The species in the first group exhibited reverse J-shaped distribution, which indicates stable population structures. The species in the second group showed relatively good recruitment but the regeneration is negatively affected. The species in the other three groups exhibited hampered regeneration as a result of disturbances caused by humans, domestic animals and annual fires. The parameters assessed indicate the need for attention and appropriate management interventions by the relevant national authorities at various levels.
\end{abstract}

Keywords: Density; Dominance; Floristic Similarity; Frequency; Grazing; Important Value Index; Species Richness

\section{Introduction}

Dry forests and woodlands, including those in Botswana, form more than $40 \%$ of all tropical forests, and Africa and tropical islands of the world house the largest proportion of dry forest and woodland ecosystems where they account for $70 \%$ $80 \%$ of the forested area (Murphy \& Lugo, 1986). Tropical dry forests and woodlands have been under exploitation for thousands of years since they have often been preferred for human settlement to wetter forest zones for biological and ecological reasons (Murphy \& Lugo, 1986; Janzen, 1988). As a result, they are either vanishing or being degraded rapidly due to accelerated growth of human and livestock populations, which result in the conversion of forested land to agriculture and excessive exploitation of forests for fuelwood, construction material and timber for export. For instance, of all the harvested wood in the tropics, $80 \%$ is used for fuel purposes, and the proportion is higher $(90 \%)$ in the African tropics, where dry

*Corresponding author. forests are predominant (Murphy \& Lugo, 1986). A typical example is Kenya, which obtains $74 \%$ of its energy requirements from wood (Lamprecht, 1989).

Janzen (1988) has also argued that the threat to the tropical dry forests is multiple as well as complex, and tropical dry forests are the most threatened of the major tropical forest types, emphasising the urgent need for studying, conserving and restoring tropical dry forest ecosystems. The loss or degradation of forests results in land degradation in the form of soil erosion and decline of fertility, decline or loss of biodiversity and water bodies, impoverishment of ecosystems and global warming, which affect the welfare of humans, plants, animals and micro-organisms negatively (Teketay, 2004-2005).

The challenge generated by the reduction and degradation of forest cover can be adequately met only if serious efforts are made, on the one hand, to maintain the remaining forests and on the other to restore deforested and degraded areas (Teketay, 1996a). This requires understanding of the diversity and natural dynamics of woody species, i.e. causes, mechanisms and fac- 
tors that drive the process of regeneration of woody species as well as population change and replacement through time (Gomez-Pompa et al., 1991; Teketay, 1996a).

Therefore, studies on population structure and density of major canopy tree species can help to understand the status of regeneration of species, and, thereof, management history and ecology of the forest or woodland (Harper, 1977; Lykke, 1998; Sano, 1997; Teketay, 2005a, 2005b; Mwavu \& Witkowski, 2008, 2009a, 2009b; Tesfaye et al., 2010). Plant population structure shows whether or not the population has a stable distribution that allows continuous regeneration to take place (Rao et al., 1990; Teketay, 1997a; Tesfaye et al., 2002; Mwavu \& Witkowski, 2008, 2009a, 2009b; Tesfaye et al., 2010). If regeneration was taking place continuously, then, the distribution of species cohorts would show reverse J-shaped curve, which is an indicator of stable regeneration (Harper, 1977; Teketay, 1997a, 2005a, 2005b; Mwavu \& Witkowski, 2009b). Hence, analyses of population structures, using frequency distribution of diameter classes of naturally regenerated woody species, can provide an insight into their regeneration status (Sano, 1997; Lykke, 1998; West et al., 2000; Obiri et al., 2002; McLaren et al., 2005; Mwavu \& Witkowski, 2008, 2009b), which plays a key role in the promotion of their sustainable management, utilization and conservation.

Several studies in Benin (Sokpon \& Biaou, 2002), Burkina Faso (Savadogo et al., 2007; Zida et al., 2007; Pare et al., 2009; Bognounou et al., 2010; Sop et al., 2011), Ethiopia (Teketay, 1997a; 2005a, 2005b; Tesfaye et al., 2010; Teketay, 2011; Fiseha et al., 2013), Ghana (Swaine et al., 1990), Oman (ElSheikh, 2013), South Africa (Shackleton, 1993; Helm \& Witkowski, 2012), Tanzania (Luoga et al., 2004), Uganda (Tabuti, 2007; Mwavu \& Witkowski, 2008, 2009a, 2009b; Kalema, 2010), South Africa (Obiri et al., 2002; Venter \& Witkowski, 2010; Helm \& Witkowski, 2012) and West Africa (Poorter et al., 1996) demonstrated the crucial role of natural regeneration in the sustainable management of forest and woodland resources.

Forest $(20 \%)$ and woodland $(60 \%)$ resources cover $80 \%$ of the total land area of Botswana (FAO, 2010). Despite the relatively high forest and woodland cover, research undertakings on the various attributes of these resources are not adequate. The research activities carried out so far focused on investigations on the various attributes of woody species in relation to elephants and fire (e.g. Ben-Shahar, 1993, 1996a, 1996b, 1998a, 1998b; Ben-Shahar \& Macdonald, 2002; Robinson et al., 2002; Heinl et al., 2004; Rutina, 2004; Makhabu, 2005a, 2005b; Rutina et al., 2005; Makhabu et al., 2006; Heinl et al., 2007; Rampart, 2007; Heinl et al., 2008; Tacheba et al., 2009; Kalwij et al., 2010; Aarrestad et al., 2011; Mmolotsi et al., 2012).

A long-term study has been set up and carried out since 1997 on three pairs of permanent (fenced and unfenced) plots established in the Mokolodi Nature Reserve, southeastern Botswana (Skarpe, 1990a, 1990b, 1992; Käller, 2003; Bengtsson-Sjörs, 2006; Leife, 2010; Aarrestad et al., 2011; Herrera, 2011). These studies have been monitoring to assess the dynamics of woody species over time.

Also, although it has never been implemented, an inventory has been carried out to develop the management plan of Chobe Forests in 1993 (NFS, 1993). Other studies have also been conducted focusing on different aspects of the vegetation resources in northern Botswana (Ringrose et al., 1998; Ringrose et al., 1999; Bonyongo et al., 2000; Sekhwela et al., 2000; Sekhwela, 2003; Barnes, 2001; Moleele et al., 2001; Ringrose \& Mathe- son, 2001; Moleele et al., 2002; Mosugelo et al., 2002; Ringrose et al., 2002; Ringrose, 2003; Neudeck et al., 2012; Babitseng \& Teketay, 2013).

However, knowledge about diversity, population structure and natural regeneration of woody species is still scanty or lacking in Botswana. Particularly, no studies have been undertaken on these themes in areas where flood recession (locally known as molapo, plural melapo) farming (Oosterbaan et al., 1986; Bendsen, 2002; Vanderpost, 2009; Motsumi et al., 2012) is practiced by farmers in Ngamiland District, northern Botswana (Figure 1). Molapo farming is mainly practiced in the Okavango Delta and involves clearing of vegetation from fields in seasonally flooded areas for agriculture as well as lopping branches (Figure 2(A)) and cutting trees for fencing farms (Figure 2(B)) and kraals (Figure 3(A)). The clearing of vegetation may affect the diversity, population structure and natural regeneration of woody species as well as predispose the areas to erosion.

The specific objectives of the study were to: 1) investigate the species richness, diversity and evenness of woody species; 2) assess similarities in composition of woody species between the two study sites; 3) determine the density, frequency and domin-
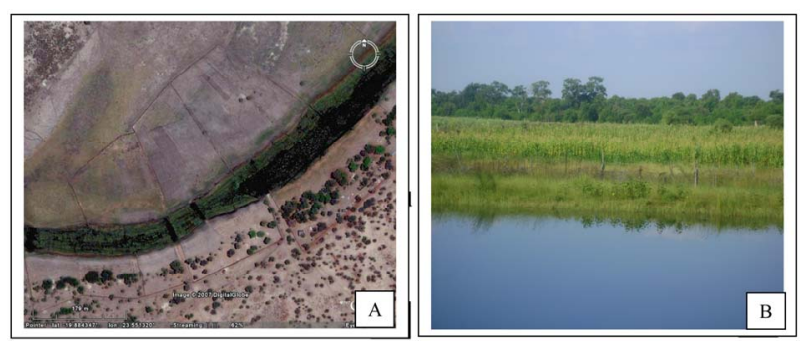

\section{Figure 1.}

Molapo farms, partly flooded (A) (VanderPost, 2009) and an example of a molapo farm with maize ((B), picture taken by Demel Teketay), in the Okavango Delta, northern Botswana.
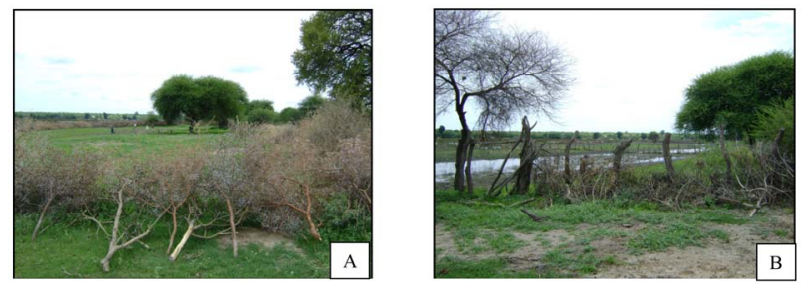

\section{Figure 2.}

Molapo farms cleared and fenced with lopped branches (A) and stems (B) cut from woody species growing naturally at Xobe (pictures taken by Demel Teketay).
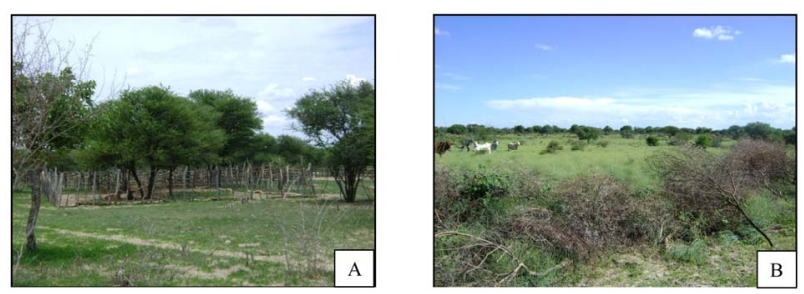

Figure 3.

Woody plants cut and used for constructing kraals (A) and large areas cleared of woody vegetation for dryland rain-fed agriculture (B) at Xobe (pictures taken by Demel Teketay). 
ance and important value indices of woody species in the study sites; and (iv) assess the population structure and regeneration status of woody species in the study sites.

\section{Study Sites}

The study was carried out in Xobe and Shorobe Villages, located in the Ngamiland District, northern Botswana (Figure 4(a)). The two villages have been identified as suitable sites since they have different flooding patterns (Figure 4(b)) and local topography and, consequently, variations in molapo farming practices (Chimbari et al., 2009). The two villages fall within the Okavango Delta, part of the wetland system, which starts in the highlands of Angola. The molapo farming system in these areas is dependent upon the rainfall at the source averaging $1400 \mathrm{~mm}$ per year with the Okavango Delta receiving an

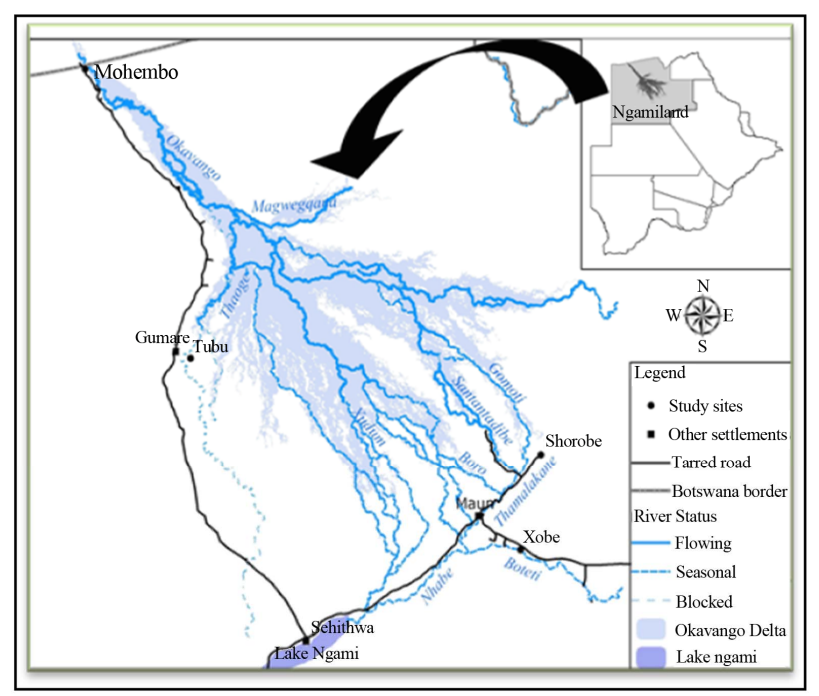

(a)

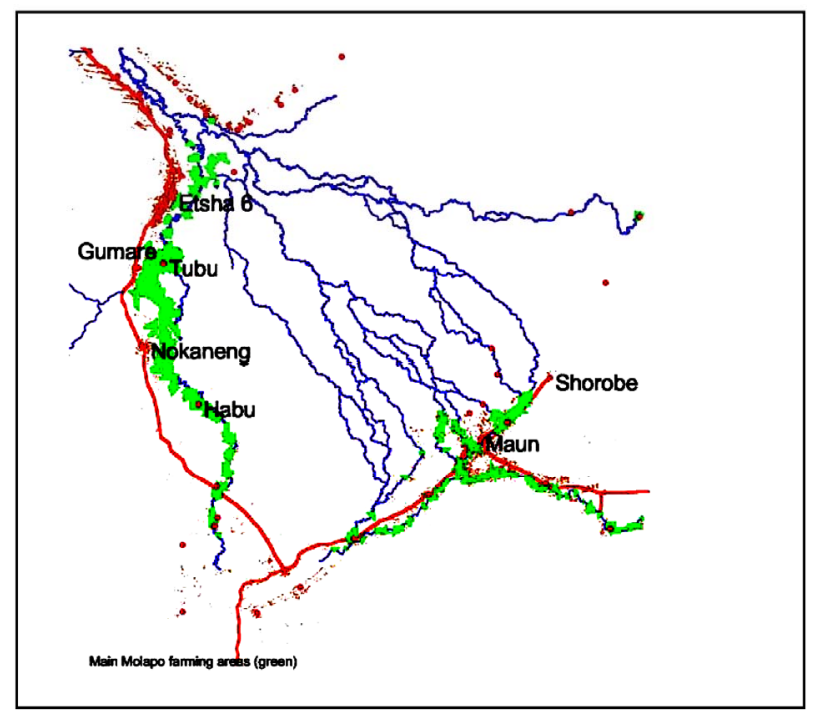

(b)

Figure 4.

Map showing study sites ((a), Chimbari et al., 2009) and the main molapo farming areas in the Okavango Delta ((b), VanderPost, 2009), northern Botswana. average of 450 - $500 \mathrm{~mm}$ per year (McCarthy et al., 1998). The vegetation in Shorobe and Xobe is dominated by mopane [Colophospermum mopane (J. Kirk ex Benth.) J. Kirk ex Leonard] and mixed species of Acacia, respectively (DEA, 2008).

Shorobe Village is located in Ngamiland East Sub-District, about $36 \mathrm{~km}$ northeast of Maun. It lies between 19 45'56.71" latitude and $23^{\circ} 40^{\prime} 10.53^{\prime \prime}$ longitude and has a population of 1031 (CSO, 2011). To the northwest of the village, there is an extensive network of molapo fields fed by the Santantadibe and Gomoti Rivers and by backflow from the Thamalakane River. Soils in molapo fields are classified as young alluvial soils. Texture varies from clayey ( $35 \%$ to $60 \%$ clay), especially in low-lying areas, through fine loamy (18\% to $35 \%$ clay) to coarse loamy ( $<18 \%$ clay) (Chimbari et al., 2009). Flooding of most molapo fields has not occurred for several years until flood waters returned in 2009. When floods occur, molapo fields are cultivated as the flood recedes. The villagers practise both arable and pastoral farming. The main crops planted are maize, sorghum, millets, pumpkins, water melons, melons, sweet reeds, beans and groundnuts. The local people are also engaged in traditional beer brewing and palm wine making, fishing and basket weaving.

Xobe Village, with a population of 418 (CSO, 2011) people, is a cattlepost area on the south bank of the Boteti River, about $13 \mathrm{~km}$ east of Maun. The area lies between $20^{\circ} 7^{\prime} 10.26^{\prime}$ latitude and $23^{\circ} 27^{\prime} 41.26^{\prime \prime}$ longitude. The river normally floods in July, but in dry years (e.g. in the late 1990s), the flood may not reach the settlement. Soils in Xobe settlement molapo fields are coarse textured alluvial deposits (Chimbari et al., 2009). Livelihood activities for people in Xobe settlement include rain-fed farming, molapo farming, irrigated vegetable production and livestock rearing. Molapo farmers cultivate along the river banks as the water flow recedes. Ploughing is done using donkeys, though smaller areas may be cultivated with hand hoes. The main crops planted are maize, pumpkins, sweet sorghum and gourds. Other activities include harvesting of wild plants for sale and fishing.

\section{Data Collection}

At both study sites, three molapo fields (replicates), at least one kilometer apart, and having adjacent vegetation were randomly selected for the study. To assess plant diversity (species richness and evenness) and density, abundance, frequency, dominance (basal area), population structure, regeneration status and important value indices of the woody species, three one kilometre long (depending on the size of the field) parallel line transects, 50 meters apart, were used in each molapo field. Quadrats measuring $20 \times 20 \mathrm{~m}$ were laid down at every 50 meters interval along the line transects.

A total of 111 quadrats representing a total area of 4.44 ha were sampled to assess the woody vegetation at Shorobe. Similarly, a total of 130 quadrats representing a total area of 5.2 ha were sampled to assess the woody vegetation at Xobe. The number of quadrats in Shorobe were lower than those in Xobe since one of the sites used for the survey had shorter transects because of the surrounding settlements.

In each of the quadrats, the following parameters were recorded: identity of all woody species (WS), number of live individuals of all WS and diameter at breast height (DBH) of all woody species (with DBH $>2 \mathrm{~cm}$ ), except juveniles (seedlings and coppices). In the case of seedlings and coppices, the 
number of individuals of each species was counted and recorded in each quadrat. A calliper and graduated measuring stick were used to measure diameter, respectively, of the woody plants.

Plant species identification was done first directly in the field using relevant manuals and other reference materials as well as with the help of local people familiar with the flora. Plant nomenclature in this article follows that of Setshogo and Venter (2003) and Setshogo (2005).

\section{Data Analyses}

Species richness $(S)$ is the total number of different woody species recorded in each of the project sites. It does not take into account the proportion and distribution of each species at the project sites.

The diversity of woody species was analysed by using the Shannon Diversity Index $(H)$ (also known as the ShannonWeiner/Weaver Diversity Index in the ecological literature) (Krebs, 1989; Magurran, 2004). The index takes into account the species richness and proportion of each species in all sampled quadrats of each project site. The following formula was used to analyse woody species diversity:

$$
H^{\prime}=\sum_{i=1}^{S} P_{i} \ln P_{i}
$$

where, $H^{\prime}=$ Shannon index, $S=$ species richness, $P_{i}=$ proportion of $S$ made up of the $i^{\text {th }}$ species (relative abundance).

Evenness or equitability, a measure of similarityof the abundances of the different woody species in the sampled project sites, was analysed by using Shannon's Evennessor Equitability Index (E) (Krebs, 1989; Magurran, 2004). Equitability assumes a value between 0 and 1 with 1 being complete evenness. The following formula was used to calculate evenness.

$$
J^{\prime}=H^{\prime} / \ln \mathrm{S}
$$

where, $J^{\prime}=$ evenness and $S=$ species richness.

The similarity in woody species composition of the two sites was computed by using Jaccard's Similarity Coefficient $\left(S_{J}\right)$ (Krebs, 1989). The values of $S_{J}$ range between 0 and 1: 0 indicates complete dissimilarity and 1 indicates complete similarity in species composition. The following formula was used to determine similarity of the woody species in the two sites:

$$
S_{J}=a /(a+b+c)
$$

where, $a=$ number of woody species common in the two sites; $b=$ number of woody species recorded only in Xobe; and $c=$ woody species recorded only in Shorobe.

The mean density (MDE) of woody species was determined by converting the total number of individuals of each woody species encountered in all the quadrats and all transects of the three replicated areas in each of the two sites to equivalent number per hectare as described in Mueller-Dombois and Ellenberg (1974). Student's t-test, at the confidence level of $P<$ 0.05 (Zar, 1999), was used to assess if differences existed between the mean values of total densities of woody species at Xobe and Shorobe.

The frequency (MF) was calculated as the proportion (\%) of the number of quadrats in which each woody species was recorded from the total number of quadrats in each of the sites. The dominance of the woody species, with diameter at breast height (DBH) of $>2 \mathrm{~cm}$, was determined from the space occu- pied by a species, usually its basal area (BA). The mean dominance of each species was computed by converting the total basal area of each woody species to equivalent basal area per hectare (Kent \& Coker, 1992).

The important value index (IVI) indicates the relative ecological importance of a woody species in each of the project sites (Kent \& Coker 1992). It is determined from the summation of the relative values of density, frequency and dominance of each woody species. Relative density (RMDE) was calculated as the percentage of the density of each species divided by the total stem number of all species $\mathrm{ha}^{-1}$. Relative frequency (RMF) of a species was computed as the ratio of the frequency of the species to the sum total of the frequency of all species. Relative dominance (RMDO) was calculated as the percentage of the total basal area of a species out of the total basal areas of all species.

Population structure of each woody species in each of the two project sites was assessed through histograms constructed by using the density of individuals of each species (Y-axis) categorized into ten diameters classes (X-axis) (Peter, 1996), i.e. $1=<2 \mathrm{~cm} ; 2=2-5 \mathrm{~cm} ; 3=5-10 \mathrm{~cm} ; 4=10-15 \mathrm{~cm} ; 5=15$ $20 \mathrm{~cm} ; 6=20-25 \mathrm{~cm} ; 7=25-30 \mathrm{~cm} ; 8=30-35 ; 9=35-40$; $10=>40 \mathrm{~cm}$. Then, based on the profile depicted in the population structures, the regeneration status of each woody species was determined.

\section{Results}

\section{Species Richness, Diversity and Evenness}

A total of 46 different species of woody plants representing 16 families and 24 genera were recorded from the two sites. Only two species, one species at each site, were not identified. Of these, 27 (10 families and 14 genera) and 41 (15 Families and 23 genera) woody species were recorded at Xobe and Shorobe, respectively (Tables 1 and 2). Fabaceae (Leguminosae) was the most diverse family at both Xobe and Shorobe represented by 12 (about 46\%) and 15 (about 38\%) woody species, respectively. The second and third most diverse families were Combretaceae [with 4 species (about 15\%) at Xobe and 6 species $(15 \%)$ at Shorobe] and Tiliaceae [with 3 species (about 12\%) at Xobe and 4 species $(10 \%)$ at Shorobe], respectively. Capparaceae, Ebenaceae and Rhamnaceae were represented by two species (5\%) each at Shorobe. All other families contained only one species at both sites. Ten genera and six families were found only in Shorobe while one genus and one family were found only in Xobe (Tables 1 and 2).

Of the 24 genera encountered, 14 and 23 were recorded from Xobe and Shorobe, respectively. At both sites, Acacia was the most diverse genus with 8 (about 57\%) and 9 (about 39\%) species of the total number of genera at Xobe and Shorobe sites, respectively. Combretum and Grewia [with 3 species (about $21 \%$ ) each] were the second diverse genera followed by Philoneptera [with 2 species (about 14\%)] at Xobe. Similarly, Combretum and Grewia [with 4 species (about 17\%) each] were the second diverse genera followed by Philoneptera, Albizia and Terminalia [with 2 species (about 9\%) each] at Shorobe. All the other genera were represented only by one species at both sites (Tables 1 and 2).

The diversity and evenness of woody species were 1.5 and 0.5 in Xobe, respectively, and 2.18 and 0.6 in Shorobe, respectively. 
Table 1.

List of woody species recorded from Xobe with their densities (individuals ha $\left.{ }^{-1}\right)$, frequencies $(\%)$, dominance $\left(\mathrm{m}^{2} \cdot \mathrm{ha}^{-1}\right)$, relative values $(\%)$ of densities, frequencies and dominance as well as Important Value Index $(\mathrm{MDE}=$ mean density, $\mathrm{MF}=$ mean frequency, $\mathrm{MDO}=$ mean dominance, $\mathrm{RMDE}=$ relative mean density, $\mathrm{RMF}=$ relative mean frequency, $\mathrm{RMDO}=$ relative mean dominance and IVI = important value index).

\begin{tabular}{|c|c|c|c|c|c|c|c|c|c|}
\hline Species & Family & Local names & MDE & MF & MDO* & RMDE & RMF & RMDO & IVI \\
\hline Acacia mellifera ${ }^{\mathrm{F}}$ & Fabaceae & Mongana & 1194.3 & 82.2 & 33.4 & 45.8 & 19.2 & 25.2 & 90.2 \\
\hline Acacia tortilis ${ }^{\mathrm{F}}$ & Fabaceae & Mosu & 1068.4 & 69.9 & 49.7 & 37.5 & 16.2 & 36.1 & 89.8 \\
\hline Philenoptera nelsii & Fabaceae & Mohatha & 106.1 & 35.9 & 22.2 & 3.7 & 8.2 & 16.1 & 27.9 \\
\hline Acacia luederitzii $^{\mathrm{F}}$ & Fabaceae & Mokgwelekgwele & 49.3 & 28.3 & 10.6 & 1.7 & 6.5 & 7.6 & 15.7 \\
\hline Acacia erubescens ${ }^{\mathrm{F}}$ & Fabaceae & Moloto & 45.9 & 24.6 & 2.5 & 1.5 & 5.6 & 1.7 & 8.9 \\
\hline Albizia anthelmintica & Fabaceae & Monoga & 37.5 & 13.8 & 2.5 & 1.2 & 3.1 & 2.0 & 6.3 \\
\hline Acacia erioloba $^{\mathrm{F}}$ & Fabaceae & Mogotho & 37.0 & 27.0 & 4.6 & 1.4 & 6.5 & 3.5 & 11.4 \\
\hline Gymnosporia senegalensis & Celastraceae & Mothono & 36.3 & 20.8 & 0.3 & 1.2 & 4.8 & 0.2 & 6.3 \\
\hline Terminalia prunioides & Combretaceae & Motsiara & 35.9 & 21.4 & 2.3 & 1.2 & 4.7 & 1.8 & 7.7 \\
\hline Gardenia volkensii & Rubiaceae & Morala & 26.1 & 6.1 & 0.6 & 0.9 & 1.4 & 0.4 & 2.7 \\
\hline Mimusops zeyheri & Sapotaceae & Mmupudu & 23.9 & 12.1 & 0.2 & 0.8 & 2.7 & 0.1 & 3.6 \\
\hline Combretum albopunctatum & Combretaceae & Motsoketsane & 20.4 & 22.8 & 1.8 & 0.7 & 4.9 & 1.2 & 6.8 \\
\hline Ximenia americana & Olacaceae & Moretologa & 13.0 & 8.5 & 0.0 & 0.5 & 2.2 & 0.0 & 2.7 \\
\hline Croton megalobotrys ${ }^{\mathrm{F}}$ & Euphorbiaceae & Motsebe & 11.9 & 2.2 & 0.5 & 0.4 & 0.5 & 0.3 & 1.2 \\
\hline Dichrostachys cinerea & Fabaceae & Moselesele & 10.5 & 15.2 & 0.1 & 0.4 & 3.5 & 0.1 & 4.0 \\
\hline Grewia flava & Tiliaceae & Moretlwa & 7.6 & 16.8 & 0.0 & 0.3 & 3.7 & 0.0 & 3.9 \\
\hline Combretum hereroense ${ }^{\mathrm{F}}$ & Combretaceae & Mokabi & 6.9 & 2.2 & 0.4 & 0.2 & 0.5 & 0.2 & 0.9 \\
\hline Grewia retinervis & Tiliaceae & Mokgomphata & 5.5 & 13.0 & 0.0 & 0.2 & 2.9 & 0.0 & 3.1 \\
\hline Acacia galpinii & Fabaceae & Mokala & 2.6 & 0.7 & 0.2 & 0.1 & 0.2 & 0.1 & 0.4 \\
\hline Boscia albitrunca & Capparaceae & Motopi & 1.8 & 5.9 & 2.8 & 0.1 & 1.4 & 2.2 & 3.7 \\
\hline Ziziphus mucronata $^{\mathrm{F}}$ & Rhamnaceae & Mokgalo & 1.4 & 2.3 & 0.0 & 0.0 & 0.5 & 0.0 & 0.6 \\
\hline Acacia nilotica & Fabaceae & Motlhabakgosi & 1.2 & 0.8 & 0.0 & 0.1 & 0.2 & 0.0 & 0.3 \\
\hline Acacia fleckii ${ }^{\mathrm{F}}$ & Fabaceae & Mohahu & 0.6 & 0.8 & 0.5 & 0.0 & 0.2 & 0.4 & 0.6 \\
\hline Combretum mossambicense & Combretaceae & Motsweketsane & 0.6 & 0.8 & 0.0 & 0.0 & 0.2 & 0.0 & 0.3 \\
\hline Philenoptera violacea & Fabaceae & Mopororo & 0.4 & 1.6 & 0.4 & 0.0 & 0.3 & 0.3 & 0.7 \\
\hline Unidentified species & - & - & 0.4 & 0.8 & 0.5 & 0.0 & 0.2 & 0.4 & 0.6 \\
\hline Grewia bicolor & Tiliaceae & Mogwana & 0.2 & 0.8 & 0.0 & 0.0 & 0.2 & 0.0 & 0.2 \\
\hline Total & & & 2745.7 & & & 100 & 100 & 100 & \\
\hline
\end{tabular}

"The " 0 " values indicate several decimal places, i.e. close to zero; ${ }^{\mathrm{F}}=$ species most preferred for fencing (Chimbari et al., unpublished).

\section{Similarities in Composition of Woody Species}

Of the 46 woody species, 22 were recorded at both sites while 5 and 19 woody species were recorded only from Xobe and Shorobe sites, respectively (Tables 1 and 2). The similarities of woody species in terms of richness of species, genera and families at the two sites were about $50 \%, 54 \%$ and $56 \%$, respectively.

\section{Density, Frequency and Dominance}

The total mean densities of woody species were $2745.7 \pm$ $1.35(\mathrm{SD})($ range $=2222-6545)$ and $4269.7 \pm 36(\mathrm{SD})$ (range 2155 - 3133) individuals $\mathrm{ha}^{-1}$ at Xobe and Shorobe, respectively, and ranged from 0.2 (G. discolor) - 1194.3 (A. mellifera) at Xobe and 0.2 (E. divinorum) - 1675.4 (C. mopane) (Tables 1 and 2). Despite differences in absolute numbers, the total mean 
Table 2.

List of woody species recorded from Shorobe with their densities (individuals ha $\left.{ }^{-1}\right)$, frequencies $(\%)$, dominance $\left(\mathrm{m}^{2} \cdot \mathrm{ha}^{-1}\right)$, relative values $(\%)$ of densities, frequencies and dominance as well as Important Value Index (MDE = mean density, MF = mean frequency, $\mathrm{MDO}=$ mean dominance, $\mathrm{RMDE}=$ relative mean density, $\mathrm{RMF}=$ relative mean frequency, $\mathrm{RMDO}=$ relative mean dominance and IVI $=$ important value index).

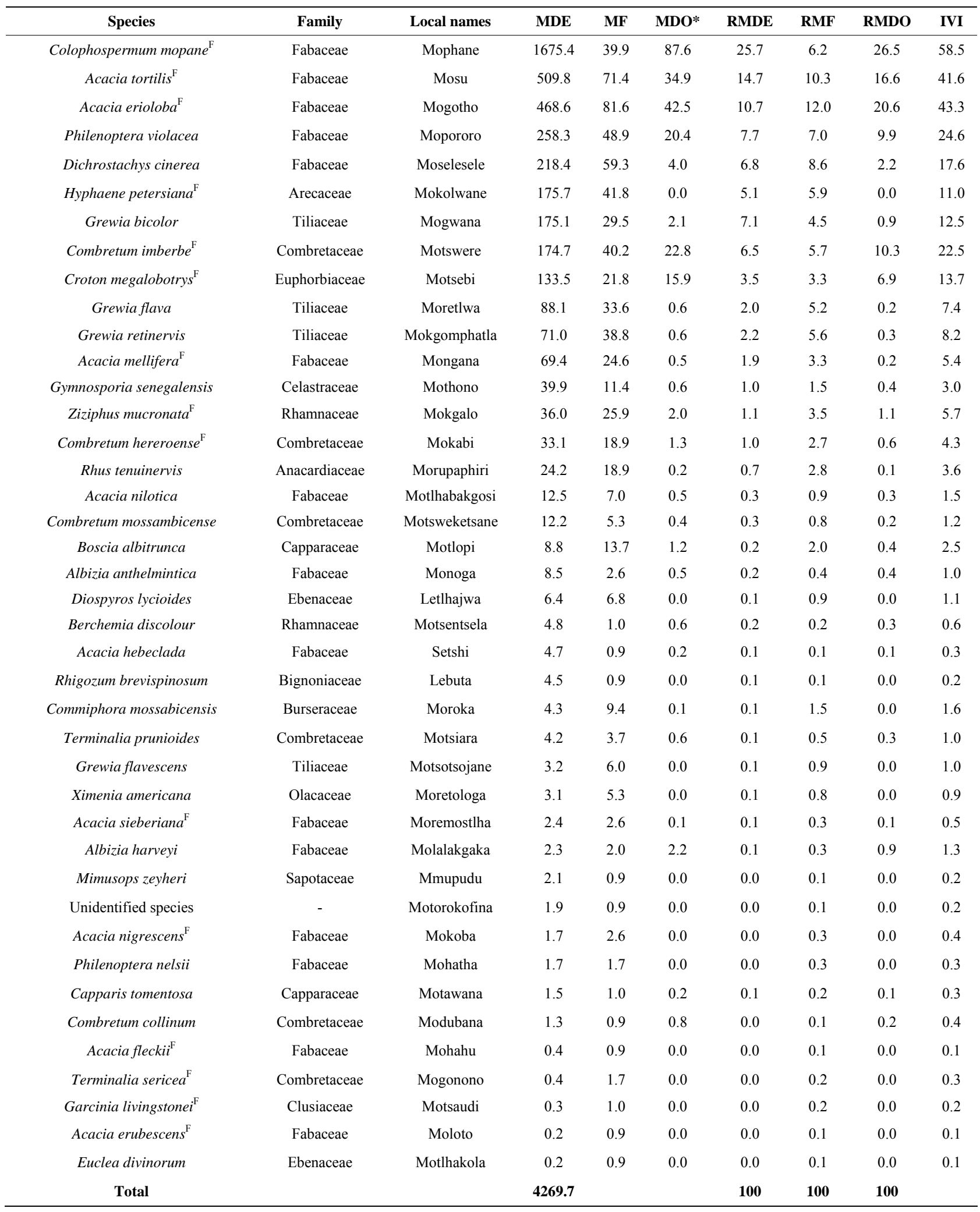

"The " 0 " values indicate several decimal places, i.e. close to zero; ${ }^{\mathrm{F}}=$ species most preferred for fencing (Chimbari et al., unpublished). 
densities of woody species at both sites did not exhibit significant differences (Students T-Test, $P=0.35$ ).

The top 10 densest woody species at Xobe were (in descending order of density) Acacia mellifera, A. tortilis, Philenoptera nelsii, Acacia luederitzii, A. erioloba, A. erubescens, Terminalia prunioides, Combretum albopunctatum, Albizia anthelmintica and Gymnosporia senegalensis (Table 1). The least five densest woody species at Xobe were (in descending order of density) Acacia fleckii, Combretum mossambicense, Philenoptera violacea, Unidentified sp. and Grewia bicolor. The 10 densest woody species at Shorobe were (in descending order of density) Colophospermum mopane, Acacia tortilis, A. erioloba, Philenoptera violacea, Dichrostachys cinerea, Hyphaene petersiana, Grewia bicolor, Combretum imberbe, Croton megalobotrys and Grewia retinervis (Table 2). The least five densest woody species at Shorobe were (in descending order of density) Acacia fleckii, Terminalia sericea, Garcinia livingstonei, Acacia erubescens and Euclea divinorum.

Acacia erioloba, A. erubescens, A. fleckii, A. galpinii, A. luederitzii, A. mellifera, A. nilotica, A. tortilis, Albizia anthelmintica and Boscia albitrunca were the ten most frequent woody species at Xobe (in descending order of frequency) (Table 1). The five least frequent woody species were Philenoptera violacea, Terminalia prunioides, Unidentified species, Ximenia americana and Ziziphus mucronata. Acacia erioloba, Acacia tortilis, Dicrostachys cinerea, Philenoptera violacea, Hypaene petersiana, Combretum imberbe, Colophospermum mopane, Grewia retinervis, G. flava and G. bicolor were the top 10 most frequent species in Shorobe (in descending order of frequency) (Table 2). The five least frequent woody species were Combretum collinum, Acacia fleckii, Garcinia livingstonei, Acacia erubescens and Euclea divinorum.

The top 10 most dominant woody species at Xobe were (in descending order of dominance) Acacia tortilis, A. mellifera, Philenoptera nelsii, Acacia luederitzii, A. erioloba, Boscia albitrunca, Acacia erubescens, Albizia anthelmintica, Terminalia prunioides and Combretum albopunctatum (Table 1). Seven woody species $(22 \%$ the total number of species recorded at the site) had very insignificant dominance values, i.e. close to zero. These are Ximenia americana, Grewia flava, Ziziphus mucronata, Acacia nilotica, Combretum mossambicense, Grewia bicolor and the unidentified species. The top 10 most dominant woody species at Shorobe were (in descending order of dominance) Colophospermum mopane, Acacia erioloba, Acacia tortilis, Combretum imberbe, Philenoptera violacea, Croton megalobotrys, Dichrostachys cinerea, Grewia bicolor, Ziziphus mucronata and Albizia harveyi (Table 2). Sixteen of the woody species (about $39 \%$ of the total number of species recorded at the site) had very insignificant dominance values, i.e. close to zero.

\section{Important Value Index}

Based on their Importance Value Index, Acacia mellifera, A. tortilis, Philenoptera nelsii, Acacia luederitzii, A. erioloba, A. erubescens, Terminalia prunioides, Combretum albopunctatum, Albizia anthelmintica and Gymnosporia senegalensis in Xobe (Table 1) and Colophospermum mopane, Acacia erioloba, Acacia tortilis, Philenoptera violacea, Combretum imberbe, Dichrostachys cinerea, Croton megalobotrys, Grewia bicolor, Hyphaene petersiana and Grewia retinervis in Shorobe (Table 2) were the top ten species in their descending order of eco- logical importance. Nine and 16 species had IVI values of less than one in Xobe and Shorobe, respectively, indicating that they are the least ecologically important species (Tables 1 and 2).

\section{Population Structure and Regeneration Status}

Based on their population structures, the woody species recorded at Xobe and Shorobe could be categorized into five diameter class distribution patterns (Figure 5).

The first group was composed of species that exhibited higher number of individuals at the lowest diameter class and progressively declining numbers with increasing diameter classes. To this group belonged Acacia erioloba, A. tortilis, A. mellifera, Colophospermum mopane, Combretum imberbe, Dichrostachys cinerea, Grewia retinervis and Gymnosporia senegalensis at Shorobeand Combretum albopunctatum, Dichrostachys cinerea, Gymnosporia senegalensis and Ximenia americana at Xobe (Figure 5(a)).

The second group was composed of species with similar diameter class distribution pattern as the first group except that individuals are missing at the higher diameter classes. To this group Commiphora mossabicensis, Diospyros lycioides, Grewia flavescens and Rhus tenunervis at Shorobe and Acacia luederitzii, A. tortilis, Albizia anthelmintica, Terminalia prunioides and Ziziphus mucronata at Xobe (Figure 5(b)) have been categorized.

The third group consisted of species that showed both hampered seedling/coppice recruitment and missing of individuals at the higher diameter classes. To this group belonged Acacia hebeclada, A. nilotica, A. sieberiana, Albizia anthelmintica, Combretum hereroense, C. mossambicense, Croton megalobotrys, Grewia bicolor, Mimusops zeyheri and Ziziphus mucronata at Shorobe and Acacia erubescens, A. galpinii, A. mellifera, Combretum hereroense, C. mossambicense, Croton megalobotrys, Gardenia volkensii, Mimusops zeyheri and Philenoptera violacea at Xobe (Figure 5(c)).

The fourth group was composed of species with missing individuals in one or more of the diameter classes. To this group Albizia harveyi, Berchemia discolor, Boscia albitrunca, Capparis tomentosa, Combretum collinum, Grewia flava, Philenoptera violacea and Terminalia prunioides at Shorobe and Acacia erioloba, A. fleckii, A. nilotica, Boscia albitrunca, Philenoptera nelsii and the unidentified species at Xobe (Figure 5(d)) were categorized.

The fifth group consisted of species with individuals represented only in the first diameter class or juveniles. This group was composed of Acacia erubescens, A. fleckii, A. nigrescens, Euclea divinorium, Garcinia livingstonei, Hyphaene petersiana, Philenoptera nelsii, Rhigozum brevispinosum, "Motorokofina" (unidentified sp.), Terminalia sericea and Ximenia Americana at Shorobe and Grewia bicolor, G. flava and G. retinervis at Xobe (Figure 5(e)).

\section{Discussion}

Forest and woodland resources in Botswana are important in providing socio-economic and ecological services, e. g. timber, food, fuelwood, traditional medicine, fodder, other non-timber forest products, source of grazing areas, wildlife habitats, tourism, watershed regulation, soil protection, carbon sequestration and storage, etc., that sustain livelihoods of communities and 


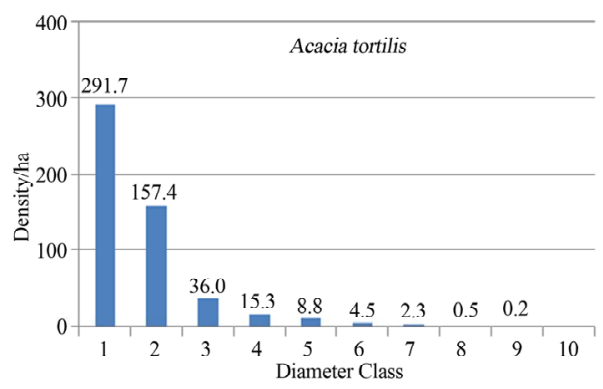

(a)

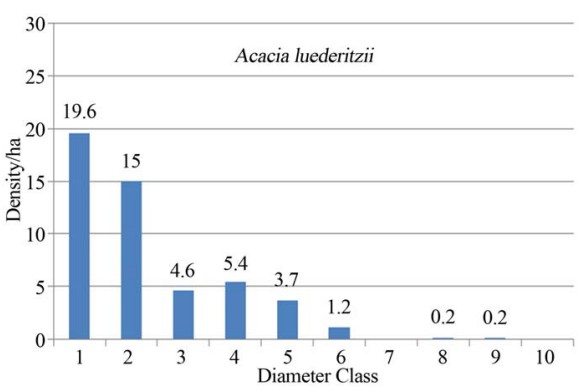

(b)

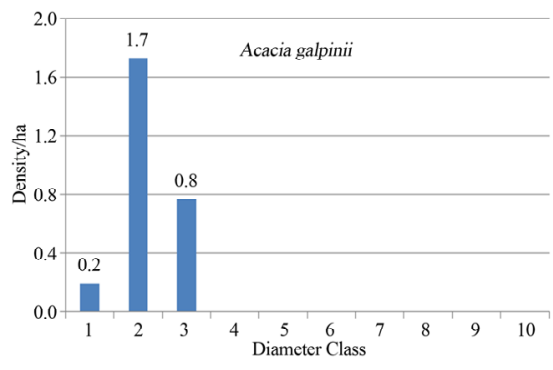

(c)

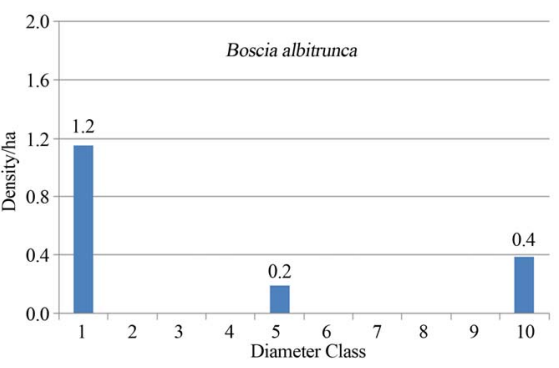

(d)

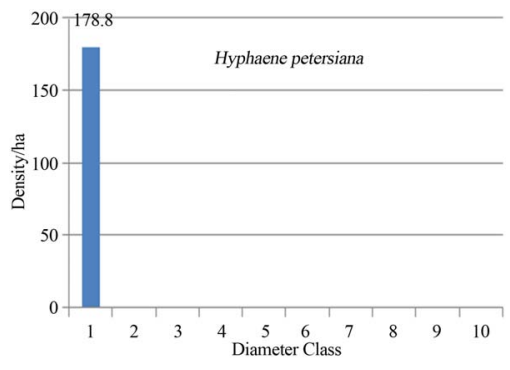

(e)

Figure 5.

Population structure of woody species recorded at Shorobe ((a) and (e)) and Xobe ((b), (c) and (d)) [diameter class (DBH): $1=<2 \mathrm{~cm} ; 2=2-5 \mathrm{~cm}$; $3=5-10 \mathrm{~cm} ; 4=10-15 \mathrm{~cm} ; 5=15-20 \mathrm{~cm} ; 6=20-25 \mathrm{~cm} ; 7=25-30 \mathrm{~cm} ; 8=30-35 ; 9=35-40 ; 10=>40 \mathrm{~cm}$.

the national economy. Therefore, their sustainable management, utilization and conservation are crucial.

Measures of species diversity play a central role in ecology and conservation biology (Magurran, 2004) since species diversity is an important parameter of a plant community, one of the major criteria for nature conservation and connected to ecosystem dynamics and environmental quality (Kalema, 2010). A change in species diversity is often used as an indicator of anthropogenic or natural disturbances in an ecosystem (Liu \& Brakenhielm, 1996; Kalema, 2010). Therefore, characterization of biodiversity through inventories can be useful in the planning of operations that aim to conserve biodiversity (Belbin, 1995; Faith \& Walker, 1996; Kelema, 2010).

Of the two study sites, Shorobe exhibited the highest species richness with 18 of the woody species not recorded from Xobe. Only five of the species recorded at Xobe were not encountered in the studied quadrats at Shorobe. Interestingly, even the densest and most dominant tree species in northern Botswana, namely C. mopane, and the common and conspicuous species, such as $H$. petersiana and Combretum imberbe at Shorobe were not recorded from the quadrats examined in Xobe, indicating their scarcity at this study site. Conversely, one of the most common species recorded in Xobe, namely A. leuderitzii, was not encountered in the quadrats sampled from Shorobe. In addition, the numbers of genera and families were higher in Shorobe than Xobe. With the exception of A. tortilis and A. erioloba, the highest densities, frequencies, dominances and, hence, IVI values were exhibited by different species in the two sites. In terms of species richness and overall diversity, Shorobe and Xobe had much lower number of woody species compared with reports from studies in the Sudanian savanna in Burkina Faso (Savadogo et al., 2007), dryland forests and woodlands in Ethiopia (Woldemariam et al., 2000; Senbeta \& Teketay, 2003; Zegeye et al., 2006, 2011; Worku et al., 2012) as well as woodlands and forests in South Africa (Dovie et al., 2008), Tanzania
(Luoga et al., 2000; Banda et al., 2008) and Uganda (Nangendo et al., 2006; Kalema, 2010). However, the evenness values of woody species in Shorobe and Xobe were comparable with those reported for other dry land forests (Senbeta \& Teketay, 2003; Alelign et al., 2007; Zegeye et al., 2006, 2011).

The overall diversity of woody plants was much higher in Shorobe $\left(H^{\prime}=2.18\right)$ than Xobe $\left(H^{\prime}=1.5\right)$, which may be a consequence of the high species richness in Shorobe. It has been noted that the value of $H^{\prime}$ obtained from empirical data usually falls between 1.5 and 3.5, and rarely surpasses 4 (Margalef, 1972; Magurran, 2004). This implies that the diversity of woody species at Xobe falls at the lowest value of the diversity range. Although we have not investigated the causes, the difference in the edaphic factors, especially the big difference in the soil types and moisture availability (Chimbari et al., 2009), may be responsible for the considerable floristic variations (richness of species, genera and families as well as overall diversity) between the two sites. The diversity values of woody species obtained at Shorobe and Xobe are lower than those reported from Miombo Woodlands in Tanzania (Nduwamungu, 1997; Zahabu, 2001) and savanna woodlands in South Africa (Dovie et al., 2008). However, evenness values of the woody species at Shorobe $(\mathrm{E}=0.6)$ and Xobe $(\mathrm{E}=0.5)$ were more or less similar, also with those from other studies (Zegeye et al., 2006, 2011; Worku et al., 2012), suggesting that individuals of the different species recorded exhibited moderately similar abundance at the two sites.

The Jaccard's Similarity Coefficients of about $50 \%$ - 56\% for the richness of species, genera and families of woody species recorded from the two sites indicate that about half of the total species, genera and families encountered were specific to one or the other site. This reality has to be taken into consideration in any plan aimed at the sustainable management and conservation of these resources.

Shorobe exhibited much higher density of woody species 
compared with that of Xobe, which could be associated with the higher number of woody species encountered at Shorobe than Xobe. With the exception of A. tortilis and A. erioloba, the two study sites differed in their densest woody species. Surprisingly, as stated above, the densest woody species in Shorobe, C. mopane, was not recorded from any of the quadrats assessed in Xobe, which may be attributed to its requirement of habitats with heavy textured and poorly drained soils (Ellery \& Ellery, 1997).

A. mellifera and A. tortilis had much higher densities at Xobe than Shorobe with more than $82 \%$ of the total density recorded in Xobe. In fact, more than $87 \%$ of the total density in Xobe was represented by the six Acacia species, five of which are also among the most dominant and frequently found species with the highest IVI values. This might suggest signs of bush encroachment due to overgrazing and over-exploitation of resources at Xobe (DEA, 2008). Acacia mellifera forms impenetrable patches of thickets at Xobe and is known to encroach eroded sites (Ellery \& Ellery, 1997) and heavily grazed areas (El-Sheikh, 2013). Acacia tortilis is also common and widespread species in Botswana, which occurs on clay or loam soils in a variety of woodlands, generally near floodplains and pans. It tends to encroach heavily grazed sites (Ellery \& Ellery, 1997). The domination of Acacia species, which are indicative of heavy grazing and encroachment, at Xobe is consistent with the fact that Xobe is used as a cattle post by people living in the nearby Maun Town.

In addition, the relatively high number of species and density of Acacia species recorded at Xobe may be attributed to seed dispersal, which is known to be facilitated by ruminants, and the subsequent favourable initial habitat for the developing seedlings within the accompanying droppings of the animals (Schultka \& Cornelius, 1997; Teketay, 1996b, 1997b, 2005a; Kalema, 2010). Many Acacia species also use the soil seed bank as one route of regeneration after disturbance, especially following fire incidences (Sabiiti \& Wein, 1987; Teketay \& Granström, 1995, 1997; Teketay, 1998; Witkowski \& Garner, 2000; Eriksson et al., 2003; Teketay, 2005a). It has been reported that grazing is a predictable selective form of disturbance with animal behaviour through browse choice playing a significant role in determining which species are impacted (Whelan, 2001; Kalema, 2010). Grazing pressure may also play a significant role in determining plant community structure and composition by facilitating bush encroachment in frequently grazed areas (Witkowski \& O’Connor, 1996; Kalema, 2010). Grazing, fire and selective tree harvesting, which are very common in the study sites, are considered major disturbances shaping species diversity and productivity (Savadogo, 2007; Kalema, 2010).

It is interesting to note that $P$. violacea had much higher densities at Shorobe than Xobe while $P$. nelsii exhibited higher density in Xobe than Shorobe. On the one hand, P. violacea grows in open woodlands on edges of islands in seasonal swamps, and occasionally on interior regions of islands in permanent swamps (Ellery \& Ellery, 1997), habitats common in the surroundings of Shorobe. On the other, P. nelsii occurs in deep sand as part of short woodlands (Ellery \& Ellery, 1997), which characterize the habitat at Xobe.

The overall density of woody species recorded at Shorobe was higher than those reported from other dry Afromontane forests (Alelign et al., 2007; Zegeye et al., 2006, 2011) and woodlands (Worku et al., 2012). The overall density of woody species recorded at Xobe was higher than other dry woodlands (Worku et al., 2012), similar to those reported from different forests (Woldemariam et al., 2000; Zegeye et al., 2006, 2011) and lower than other dry Afromontane forests (Alelign et al., 2007; Zegeye et al., 2011). The overall horizontal distribution of the woody species, represented by the frequency of occurrence of the species in the studied quadrats, was relatively low with only 10 (out of 41) and three (out of 27) species having more than $30 \%$ frequency values at Shorobe and Xobe, respectively. This implies that the other species have scarce horizontal distribution at both study sites, which requires further investigations that can assist in the future design of appropriate management interventions.

Importance Value Index is an important parameter that reveals the ecological significance of species in a given ecosystem (Lamprecht, 1989; Zegeye et al., 2006; Senbeta \& Teketay, 2003; Worku et al., 2012). Acacia mellifera, A. tortilis and Philenoptera nelsii at Xobe and Colophospermum mopane, Acacia erioloba, Acacia tortilis and Philenoptera violacea at Shorobe can be considered the most ecologically important woody species with IVI values of more than 20 contributed by their high values of density, frequency and dominance. It is interesting to note that $A$. tortilis is recorded among the most ecologically important woody species at both study sites.

In the absence of long-term demographic data on population trends, the use of diameter class distributions of woody species from a single survey has been shown to be a potential and reliable tool to reveal status of population structures and regeneration of woody species as well as predict responses of the species to disturbance and resultant changes in population structure (Condit et al., 1998; Lykke, 1998; Obiri et al., 2002; Sokpon \& Biaou, 2002; Teketay, 2005a, 2005b; Feeley et al., 2007; Tabuti, 2007; Mwavu \& Witkowski, 2009a; Tesfaye et al., 2010; Venter \& Witkowski, 2010; Sop et al., 2011; Helm \& Witkowski, 2012; El-Sheikh, 2013). A population size structure is simultaneously the outcome of past demographic events and an indicator of its demographic future (Wilson \& Witkowski, 2003; Kalema, 2010).

Based on the assessment of diameter class distributions, the population structure patterns of the woody species recorded from Shorobe and Xobe were categorized into five groups. The species in the first group exhibited reverse J-shaped distribution, which is widely acknowledged to indicate stable population structure, naturally replacing senesced individuals with seedlings and saplings (Condit et al., 1998; Lykke, 1998; Obiri et al., 2002; Teketay, 1997a; 2005a, 2005b; Tabuti, 2007; Mwavu \& Witkowski, 2009a; Tesafye et al., 2010; Sop et al., 2011; Helm \& Witkowski, 2012; El-Sheikh, 2013). This appeared to be the case for about 20 and $15 \%$ of the woody species recorded at Shorobe and Xobe, respectively. Typical examples are A. erioloba, A. tortilis and C. mopane at Shorobe and C. albopunctatum and G. senegalensis at Xobe. The species in the second group exhibited relatively good recruitment (of seedlings/coppices) but the regeneration is negatively affected as evidenced from the absence of individuals in progressively higher classes. This may be attributed to either natural- or human-induced hampered regeneration. Pole-sized and mature individuals may have been cut by the local people for various purposes. This group was comprised of about 10 and $19 \%$ of the woody species recorded at Shorobe and Xobe, respectively. The species in the other groups exhibited both naturally- and human-induced disturbances leading to their hampered regeneration. This ap- 
peared to be the case for about $70 \%$ and $66 \%$ of the woody species recorded at Shorobe and Xobe, respectively. In particular, the species in the fifth group, represented by about $27 \%$ and $11 \%$ of the woody species recorded at Shorobe and Xobe, respectively, exhibited a very serious problem of regeneration with individuals only in the first diameter class.

Some of the causes for the hampered regeneration of the woody species include clearing of the woody vegetation for cultivating crops both by molapo (Figure 2(A)) and dry land (Figure 3(B)) farmers, heavy grazing pressure, cutting of stems and lopping of branches of woody species for fencing of farms (Figures 2(A) and (B), 3(B)), kraals (Figure 3(A)) and house compounds and fuel wood. A land use assessment carried out by the University of Botswana on the basis of satellite images found that of the 48,900 ha cleared for cultivation in Ngamiland, $75 \%$ consist of dryland fields and $25 \%$ of fields in temporarily inundated floodplains (VanderPost, 2009). VanderPost (2009) also indicated that molapo farming takes place on small fields separated by strips of "natural" floodplain, and wholesale landclearing does not usually occur, although removal of some vegetation takes place.

The major impact of the molapo farming results from the heavy lopping of branches and cutting of trees of woody species used for fencing the farms. The heavy lopping of branches of woody species will negatively affect the production of fruits/seeds in enough qunatities required for the stable recruitment and regeneration of the species. However, the major impact was observed from the clearing and grazing (Figure 3(B)) of considerable areas of woody vegetation for the purpose of establishing and fencing rain-fed dry land farming (Figure 3(B)). In addition, the free grazing system in the study sites in particular and Botswana in general leads to the browsing and trampling of seedlings of woody species. At Shorobe, H. petersiana was categorized in the fifth group based on its population structure. The trees of this species are cut down at about $30 \mathrm{~cm}$ above the ground for tapping the stem sap, which is, then, processed by the local people to produce palm wine (Babitseng \& Teketay, 2012). This traditional wine tapping method, which leads to the destruction of the stems of trees, is responsible for the obvious population structure (Figure 5(e)) and, hence, hampered regeneration.

The socio-economic survey carried out at the two study sites revealed that 15 woody species (Tables 1 and 2) are most preferred for fencing, especially molapo farms (Chimbari et al., unpublished). Of these, 10 and five species recorded at Shorobe and Xobe, respectively, belong to the last three groups of population structure patterns. Six of the species recorded at Shorobe belong to the fifth group of the population structure pattern. This suggests that cutting of woody species for fenicng is contributing to the observed hampered regeneration of the species. If it is not properly managed, clearing of woody vegetation, cutting and lopping trees excessively, coupled with annual recurrent fires common in the study sites and elsewhere in Botswana, will affect the population structure of woody species negatively and, hence, reduce or prevent their potential of regeneration and, therefore, perpetuation. This will, in turn, result in the decline or loss of biodiversity ultimately. Whelan (1995) argues that frequent fire outbreak can affect population structure through elimination of certain classes or a delay in the whole recruitment process. Though information on fire tolerances for woody species is not available, fire might have caused the poor representation of individuals of some of the woody species since farmers use fire to clear woody vegetation for grazing and for farming.

\section{Conclusion}

The results revealed that Shorobe and Xobe together house 46 different woody species, which provide the local communities with various goods and services. Despite the apparent impacts from humans, domestic animals and recurrent annual fires, some of the woody species exhibited desirable values of density, frequency, dominance, IVI, population structures and regeneration status. Shorobe Village exhibited higher values of species, genus and family richness as well as relatively high diversity and overall density of woody species than Xobe Village. This may be attributed to the difference in the edaphic factors, especially the big difference in the soil types and moisture availability, as well as the relatively higher human- and domestic animal-induced disturbances at Xobe than Shorobe. The similarities of woody species in terms of richness of species, genera and families were medium suggesting that each site has its own characteristic species, genera and families. This is particularly important to consider when planning activities aimed at the responsible management, sustainable utilization and conservation of the woody vegetation at the study sites.

At both sites, the frequency of woody species was relatively low with the exception of a few species, suggesting that individuals of the species are thinnly or very thinnly spread horizontally. This is also evident from the medium evennes values recorded from the two study sites. Some of the woody species, especially those categorized in population structure Groups 3-5, exhibited negatively affected popultion structures and, as a result, hampered regeneration, which requires special attention and appropriate management intervention by the concerned bodies.

The results revealed relatively low diversity and overall density at Xobe. Also, relatively low evenness indices, which were caused by the sparse to very sparse horizontal distribution of individuals, were recorded at both sites. Many of the woody species exhibited low values of densities, basal areas and IVI values, unstable population structure and hampered regeneration at both study sites. These results indicate the need for attention and appropriate management interventions by the relevant national authorities at various levels, including the Kgosi (Chiefs), Village Development Committees and local communities of the study sites.

The following are a few examples of feasible management interventions to address the problems described above.

1) Reduction of the pressure on regeneration of the woody species from the uncontrolled grazing through matching the carrying capacity of the study sites with appropriate numbers of livestock.

2) Introduction of management plans and appropriate technologies that regulate or promote the type, diameter and height classes, and number of individuals of the available woody species to be harvested for the various needs of the communities. To this effect, we are also undertaking an experiment focusing on the effect of cutting diameter and height on the re-sprouting/coppicing ability of selected woody species at the study sites (Neelo et al., unpublished) with the aim of determining the optimal cutting diameter size(s) and height(s) for maximum re-sprouting ability of the species. Once promising results are achieved, it is hoped that the optimal cutting diameter(s) and 
height(s) will be demonstrated and disseminated to the local communities to promote desirable regeneration of the woody species with appropriate and sustainable utilization.

3) Establishment of rotational exclosures (Mengistu et al., 2005; Birhane et al., 2006; Aerts et al. 2009) of the areas covered with woody species at both sites, from both human and animal disturbances, so that the species will get enough time and appropriate environmental conditions to recover from the heavy grazing that affected their regeneration.

4) Research on the life-cycle and propagation (both sexual and asexual) methods of the woody species with hampered regeneration to promote their assisted regeneration, e.g. through enrichment planting.

5) Creation of awareness of the local communities on the status of population structures, regeneration and perpetuation of the woody species in their localities so that they can promote responsible management and utilization as well as conservation of the species.

\section{Acknowledgements}

Authors are grateful to the International Development Research Centre (IDRC) for providing financial support for this study through the Botswana Ecohealth Project. We are thankful to Kgosi (Chiefs), Village Development Committees and local communities of the study sites, field technicians and Transport Section of the Okavango Research Institute (ORI), University of Botswana, community research assistants and Peter Smith University of Botswana Herbarium (PSUB). We are grateful to Chenamani Ntogwa for allowing us to use his compass and caliper and Amanda Tas for her voluntary help to collect, organise and analyse our data. We would also like to thank ORI and its management for its logistical support.

\section{REFERENCES}

Aarrestad, P. A., Masunga, G. S., Hytteborn, H., Pitlagano, M. L., Marokane, W., \& Skarpe, C. (2011). Influence of soil, tree cover and large herbivores on field layer vegetation along a savanna landscape gradient in northern Botswana. Journal of Arid Environments, 75, 290-297. http://dx.doi.org/10.1016/j.jaridenv.2010.10.009

Aerts, R., Nyssen, J., \& Haile, M. (2009). On the difference between "exclosures" and "enclosures" in ecology and the environment. Journal of Arid Environments, 73, 762-763.

http://dx.doi.org/10.1016/j.jaridenv.2009.01.006

Alelign, A., Teketay, D., Yemshaw, Y., \& Edwards, S. (2007). Diversity and status of regeneration of woody plants on the peninsula of Zegie, northwestern Ethiopia. Tropical Ecology, 48, 37-49.

Babitseng, T. M., \& Teketay, D. (2013). Impact of wine tapping on the population structure and regeneration of Hyphaene petersiana Klotzsch ex Mart. in northern Botswana. Ethnobotany Research \& Applications, 11, 9-27.

Banda, T., Mwangulango, N., Meyer, B., Schwartz, M. K., Mbago, F., Sungula, M., \& Caro, T. (2008). The woodland vegetation of KataviRukwa ecosystem in western Tanzania. Forest Ecology and Management, 255, 3382-3395. http://dx.doi.org/10.1016/j.foreco.2008.01.079

Barnes, M. E. ( 2001). Seed predation, germination and seedling establishment of Acacia erioloba in northern Botswana. Journal of Arid Environments, 49, 541-554. http://dx.doi.org/10.1006/jare.2001.0805

Belbin, L. (1995). A multivariate approach to the selection of biological reserves. Biodiversity and Conservation, 9, 951-963. http://dx.doi.org/10.1007/BF00058206

Bendsen, H. (2002). The dynamics of land use systems in Ngamiland: Changing livelihoods options and strategies. Maun: University of Botswana Harry Openheimer Okavango Research Centre.
Bengtsson-Sjörs, K. (2006). Establishment and survival of woody seedlingsin a semi-arid savanna in southern Botswana. Minor Field Study 123. Uppsala: Uppsala University.

Ben-Shahar, R. (1993). Patterns of elephant damage to vegetation in northern Botswana. Biological Conservation, 65, 249-256. http://dx.doi.org/10.1016/0006-3207(93)90057-8

Ben-Shahar, R. (1996a). Woodland dynamics under the influence of elephants and fire in northern Botswana. Plant Ecology, 123, 153163. http://dx.doi.org/10.1007/BF00118268

Ben-Shahar, R. (1996b). Do elephants over-utilize mopane woodlands in northern Botswana? Journal of Tropical Ecology, 12, 505-515. http://dx.doi.org/10.1017/S0266467400009731

Ben-Shahar, R. (1998a). Changes in structure of the savannah woodlands in northern Botswana following the impacts of elephants and fire. Plant Ecology, 136, 189-194. http://dx.doi.org/10.1023/A:1009708021735

Ben-Shahar, R. (1998b). Elephant density and impact on Kalahari woodland habitats. Transactions of the Royal Society of South Africa, 53, 149-155. http://dx.doi.org/10.1080/00359199809520383

Ben-Shahar, R., \& Macdonald, D. (2002). The role of soil factors and leaf protein in the utilization of mopane plants by elephants in northern Botswana. BMC Ecology, 2, 3. http://dx.doi.org/10.1186/1472-6785-2-3

Birhane, E., Teketay, D., \&Barklund, P. (2006). Actual and potential contribution of exclosures to enhance biodiversity of woody species in the drylands of Eastern Tigray. Journal of Drylands, 1, 134-147.

Bognounou, F., Tigabu, M., Savadogo, P., Thiombiano, A., Boussim, I. J., Óden, P.-C., \& Guinko, S. (2010). Regeneration of five combretaceae species along a latitudinal gradient in Sahelo-Sudanian zone of Burkina Faso. Annals of Forest Sciences, 67, 306. http://dx.doi.org/10.1051/forest/2009119

Bonyongo, C. M., Veenendaal, E. M., \& Bredenkamp, G. (2000). Floodplain vegetation of seasonal floodplains in the Nxaraga Lagoon Area Okavango Delta Botswana. South African Journal of Botany, $66,15-21$

Chimbari, M. J., Magole, L., Wiles, G., Dikgola, K., Kurugundla, N., Teketay, D., Ngwenya, B., Nyepi, M. S., Motsumi, S., Ama, K., Thakadu, O., \& Chombo, O. (2009). Application of the ecohealth approach to understand flood-recession (Molapo) farming in the context of hydro-climate variability and hydro-climate change in the Okavango Delta, Botswana. Maun: University of Botswana, Harry Oppenheimer Okavango Research Centre.

Condit, R., Sukumar, R., Hubbell, S. P., \& Foster, R. B. (1998). Predicting population trends from size distributions: A direct test in a tropical tree community. American Naturalist, 152, 495-509. http://dx.doi.org/10.1086/286186

CSO (Central Statistics Office) (2011). Botswana population and housing census. Gaborone, Botswana.

DEA (2008). Okavango delta management plan. Gaborone: Department of Environmental Affairs (DEA).

Dovie, D. B. K., Witkowski, E. T. F., \& Shackleton, C. M. (2008). Knowledge of plant resource use based on location, gender and generation. Applied Geography, 28, 311-322. http://dx.doi.org/10.1016/j.apgeog.2008.07.002

Ellery, K., \& Ellery, W. (1997). Plants of the Okavango Delta: A field guide. Durban: Tsaro Publisher.

El-Sheikh, M. A. (2013). Population structure of woody plants in the arid cloud forests of Dhofar, southern Oman. Acta Botanica Croatica, 72, 97-111. http://dx.doi.org/10.2478/v10184-012-0008-6

Eriksson, I., Teketay, D., \& Granstrom, A. (2003). Response of plant communities to fire in an Acacia woodland and a dry Afromontane forest, southern Ethiopia. Forest Ecology and Management, 177, 3950. http://dx.doi.org/10.1016/S0378-1127(02)00325-0

Faith, D. P., \& Walker, P. A. (1996). Environmental diversity: On the best possible use of surrogate data for assessing the relative biodiversity of sets of areas. Biodiversity and Conservation, 5, 399-415. http://dx.doi.org/10.1007/BF00056387

FAO (2010). Global forest resources assessment. Rome: FAO.

Feeley, K. J., Davies, S. J., Noor, N. S., Kassim, A. R., \& Tan, S. (2007). Do current stem size distributions predict future population changes? An empirical test of intraspecific patterns in tropical trees 
at two spatial scales. Journal of Tropical Ecology, 23, 191-198. http://dx.doi.org/10.1017/S0266467406003919

Fisaha, G., Hundera, K., \& Dalle, G. (2013). Woody plants' diversity, structural analysis and regeneration status of Wof Washa natural forest, North-east Ethiopia. African Journal of Ecology (in press). http://dx.doi.org/10.1111/aje.12071

Gomez-Pompa, A., Whitmore, T. C., \& Hadley, M. (1991). Paris: Rain Forest Regeneration and Management.

Harper, J. L. (1977). Population biology of plants. Lomdon: Academic Press.

Heinl, M., Sliva, J., \& Tacheba, B. (2004). Vegetation changes after single fire-events in the Okavango Delta wetland, Botswana. South African Journal of Botany, 70, 695-704.

Heinl, M., Sliva, J., Murray-Hudson, M., \& Tacheba, B. (2007). Postfire succession on savanna habitats in the Okavango Delta wetland, Botswana. Journal of Tropical Ecology, 23, 705-713. http://dx.doi.org/10.1017/S0266467407004452

Heinl, M., Sliva, J., Tacheba, B., \& Murray-Hudson, M. (2008). The relevance of fire frequency for the floodplain vegetation of the Okavango Delta, Botswana. African Journal of Ecology, 46, 350358. http://dx.doi.org/10.1111/j.1365-2028.2007.00847.x

Helm, C. V., \& Witkowski, E. T. F. (2012). Characterising wide spatial variation in population size structure of a keystone African savanna tree. Forest Ecology and Management, 263, 175-188. http://dx.doi.org/10.1016/j.foreco.2011.09.024

Herrera, A. (2011). Changes in spatial structureof woody savanna vegetationafter 11 years of exclusion of large herbivores. Minor Field Studies 162. Uppsala: Uppsala University.

Janzen, D. H. (1988). Tropical dry forests: The most endangered major tropical ecosystem. In E. O. Wilson (Ed.), Biodiversity (pp. 130-137). Washington: National Academic Press.

Kalema, V. N. (2010). Diversity, use and resilience of woody plants in a multiple land-use equatorial African savanna, Uganda. Ph.D. Thesis, Johannesbur: University of the Witwatersrand.

Käller, A. (2003). Growth pattern and reproduction of woody vegetation in a semi-arid savannain southern Botswana. Minor Field Study 86. Uppsala: Uppsala University.

Kalwij, J. M., de Boer, W. F., Mucina, L., Prins, H. H. T, Skarpe, C., \& Winterbach, C. (2010). Tree cover and biomass increase in a southern African savanna despite growing elephant population. Ecological Applications, 20, 222-233. http://dx.doi.org/10.1890/09-0541.1

Kent, M., \& Coker, P. (1992). Vegetation description and analysis. A practical approach. London: Belhaven Press.

Krebs, C. J. (1989). Ecological methodology. New York: Harper Collins Publishers.

Lamprecht, H. (1989). Silviculture in the tropics: Tropical forest ecosystems and their tree species-Possibilities and methods for their long-term utilization. Eschborn: Deutsche Gesellschaft für Technische Zusammenarbeit (GTZ) GmbH.

Leife, H. (2010). Has woody vegetation in a semi-arid savanna changed after 11 years exclusion of large herbivores? Minor Field Study 153. Uppsala: Uppsala University.

Liu, Q., \& Brakenhielm, S. (1996). Variability of plant species diversity in Swedish natural forest and its relation to atmospheric deposition. Academic Publishers, 125, 63-72.

Louga, E. J., Witkowski, E. T. F., \& Balkwill, K. (2004). Regeneration by coppicing (resprouting) of miombo (African savanna) trees in relation to land use. Forest Ecology and Management, 189, 23-35. http://dx.doi.org/10.1016/j.foreco.2003.02.001

Luoga, E. J., Witkowski, E. T. F., \& Balkwill, K. (2000). Differential utilisation and ethnobotany of trees in Kitulangalo forest reserve and surrounding communal lands, eastern Tanzania. Economics Botany, 54, 328-343. http://dx.doi.org/10.1007/BF02864785

Lykke, A. M. (1998). Assessment of species composition change in savanna vegetationby means of woody plants' size class distributions and local information. Biodiversity and Conservation, 7, 1261-1275. http://dx.doi.org/10.1023/A:1008877819286

Magurran, A. E. (2004). Measuring biological diversity. Malden and Oxford: Blackwell Publishing.

Makhabu, S. W. (2005a). Interactions between woody plants, elephants and other browsers in the Chobe Riverfront, Botswana. Doctoral
Thesis, Oslo: Norwegian University of Science and Technology.

Makhabu, S. W. (2005b). Resource partitioning within a browsing guild in a key habitat, the Chobe Riverfront, Botswana. African Journal of Ecology, 21, 641-649.

Makhabu, S. W., Skarpe, C., Hytteborn, H., \& Mpofu, Z. D. (2006). The plant vigour hypothesis revisited-How is browsing by ungulates and elephant related to woody species growth rate? Plant Ecology, 184, 163-172. http://dx.doi.org/10.1007/s11258-005-9060-9

Margalef, R. (1972). Homage to Evelyn Hutchinson, or why is there an upper limit to diversity. Transactions of the Connecticut Academy of Arts and Sciences, 44, 211-235.

McCarthy, T. S., Bloem, A., \& Larkin, P. A. (1998). Observations on the hydrology and geohydrology of the Okavango Delta, Botswana. Journal of Geology, 101, 101-117.

McLaren, K. P., McDonald, M. A., Hall, J. B., \& Healey, J. R. (2005). Predicting species response to disturbance from size class distributions of adults and saplings in a Jamaican tropical dry forest. Plant Ecology, 181, 69-84. http://dx.doi.org/10.1007/s11258-005-3497-8

Mengistu, T., Teketay, A., Hulten, H., \& Yemshaw, Y. (2005). The role of enclosures in the recovery of woody vegetation in degraded dryland hillsides of central and northern Ethiopia. Journal of Arid Environments, 60, 259-281. http://dx.doi.org/10.1016/j.jaridenv.2004.03.014

Mmolotsi, R. M., Obopile, M., Kwerepe, B. C., Sebolai, B., Rampart, M. P., Segwagwe, A. T., Ramolemana, G., Maphane, T. M., Lekorwe, L., \& Kopong, I. (2012). Studies on Mukwa (Pterocarpus angolensis D. C.) dieback in Chobe Forest Reserves in Botswana. Journal of Plant Studies, 1, 154-157. http://dx.doi.org/10.5539/jps.v1n2p154

Moleele, N., Ringrose, S., Arnberg, W., Lunden, B., \& Vanderpost, C. (2001). Assessment of vegetation indexes useful for browse (forage) prediction in semi-arid rangelands. International Journal of Remote Sensing, 22, 741-756. http://dx.doi.org/10.1080/01431160051060147

Moleele, N., Ringrose, S., Matheson, W., \& Vander Post, C. (2002). More woody plants? The status of bush encroachment in Botswana's grazing areas. Journal of Environmental Management, 64, 3-11. http://dx.doi.org/10.1006/jema.2001.0486

Mosugelo, D. K., Stein, M., Ringrose, S., \& Nellemann, C. (2002). Vegetation changes during a 36 year period in Northern Chobe National Park, Botswana. African Journal of Ecology, 40, 232-240. http://dx.doi.org/10.1046/j.1365-2028.2002.00361.x

Motsumi, S., Magole, L., \& Kgathi, D. (2012). Indigenous knowledge and land use policy: Implications for livelihoods of flood recession farming communities in the Okavango Delta, Botswana. Physics and Chemistry of the Earth, 50-52, 185-195. http://dx.doi.org/10.1016/j.pce.2012.09.013

Mueller-Dombois, D., \& Ellenberg, H. (1974). Aims and methods of vegetation ecology. New York: John Willey and Sons, Inc.

Murphy, P. G., \& Lugo, A. E. (1986). Ecology of tropical dry forest. Annual Review of Ecology, 17, 67-88. http://dx.doi.org/10.1146/annurev.es.17.110186.000435

Mwavu, N. E., \& Witkowski, E. T. F. (2008). Sprouting of woody species following cutting and tree-fall in a lowland semi-deciduous tropical rainforest, North-Western Uganda. Forest Ecology and Management, 255, 982-992. http://dx.doi.org/10.1016/j.foreco.2007.10.018

Mwavu, N. E., \& Witkowski, E. T. F. (2009a). Population structure and regeneration of multiple-use tree species in a semi-deciduous African tropical rainforest: Implications for primate conservation. Forest Ecology and Management, 258, 840-849. http://dx.doi.org/10.1016/j.foreco.2009.03.019

Mwavu, N. E., \& Witkowski, E. T. F. (2009b). Seedling regeneration, environment and management in a semi-deciduous African tropical rain forest. Journal of Vegetation Science, 20, 791-804. http://dx.doi.org/10.1111/j.1654-1103.2009.01084.x

Nangendo, G., Steege, H. T., \& Bongers, F. (2006). Composition of woody species in a dynamic forest-woodland-savannah mosaic in Uganda: Implications for conservation and management. Biodiversity and Conservation, 15, 1467-1495. http://dx.doi.org/10.1007/s10531-005-1876-z

Nduwamungu, J. (1997). Tree and shrub diversity in Miombo Wood- 
lands. A case study at SUA Kitulanghalo Forest Reserve, Morogoro, Tanzania. Master's Thesis, Morogoro: Sokoine University of Agriculture.

Neudeck, L., Avelino, L., Bareetseng, P., Ngwenya, B. N., Teketay, D., \& Motsholapheko, M. R. (2012). The contribution of edible wild plants to food security, dietary diversity and income of households in Shorobe Village, northern Botswana. Ethnobotanical Research \& Applications, 10, 449-462.

Norwegian Forestry Society (1992). Chobe forest inventory and management plan. Gaborone: Ministry of Agriculture.

Obiri, J., Lawes, M., \& Mukolwe, M. (2002). The dynamics and sustainable use of highvalue tree species of the coastal Pondoland forests of the Eastern Cape Province, South Africa. Forest Ecology and Management, 166, 131-148.

http://dx.doi.org/10.1016/S0378-1127(01)00665-X

Oosterbaan, R. J., Kortenhorst, L. F., \& Sprey, L. H. (1986). Development of flood-recession cropping in the molapo's of the Okavango Delta, Botswana. Wageningen: International Institute for Land Reclamation and Improvement.

Pare, S., Savadogo, P., Tigabu, M., Odén, P.-C., \& Ouadba, J. M. (2009). Regeneration and spatial distribution of seedling populations in Sudanian dry forests in relation to conservation status and human pressure. Tropical Ecology, 50, 339-353.

Peters, C. M. (1996). The ecology and management of non-timber forest resources. Washington: World Bank Technical Paper 322. http://dx.doi.org/10.1596/0-8213-3619-3

Poorter, L., Bongers, F., van Rompaey, A. R., \& Klerk, M. D. (1996). Regeneration of canopy tree species at five sites in West African moist forest. Forest Ecology and Management, 84, 61-69. http://dx.doi.org/10.1016/0378-1127(96)03736-X

Rampart, M. (2007). Effects of fire and elephants on the growth of Pterocarpus angolensis (Mukwa) seedlings/saplings in the Chobe Forest Reserves (Botswana). Master's Thesis, Bangor: University of Wales. http://dx.doi.org/10.1007/BF00044832

Rao, P., Barik, S. K., Pandey, H. N., \& Tripathi, R. S. (1990). Community composition and tree population structure in a sub-tropical broad-leaved forest along a disturbance gradient. Vegetatio, 88, 151162.

Ringrose, S. (2003). Characterisation of riparian woodlands and their potential water loss in the distal Okavango Delta, Botswana. Applied Geography, 23, 281-302.

http://dx.doi.org/10.1016/j.apgeog.2003.08.006

Ringrose, S., \& Matheson, W. (2001). Spatial characteristics of Riparian Woodlands in the Distal Okavango Delta. Botswana Notes and Records, 33, 101-114.

Ringrose, S., Chipanshi, A. C., Matheson, W., Chanda, R., Motoma, L., \& Magole, I. (2002). Climate and human induced woody vegetation changes in Botswana and their implications for human adaptation. Environmental Management, 30, 98-109.

http://dx.doi.org/10.1007/s00267-002-2486-0

Ringrose, S., Lesolle, D., Botshoma, T., Gopolang, B., VanderPost, C., \& Matheson, W. (1999). An analysis of vegetation cover components in relation to climatic trends along the Botswana Kalahari Transect. Botswana Notes and Records, 31, 33-52.

Ringrose, S., Matheson, W., \& Vander Post, C. (1998). Analysis of soil organic carbon and vegetation cover trends along the Botswana Kalahari Transect. Journal of Arid Environments, 38, 379-396. http://dx.doi.org/10.1006/jare.1997.0344

Robinson, J. A., Lulla, K. P., Robinson, J. A., Lulla, K. P., Kashiwagi, M., Suzuki, M., Nellis, M. D., Charles, Bussing, E., Long, W. J. L., \& McKenzie, L. J. (2002). Conservation applications of astronaut photographs of earth: Tidal-flat loss (Japan), elephant effects on vegetation (Botswana), and seagrass and mangrove monitoring (Australia). Conservation Biology, 15, 876-884. http://dx.doi.org/10.1046/j.1523-1739.2001.015004876.x

Rutina L. P. (2004). Impalas in an elephant-impacted woodland: Browser-driven dynamics of the Chobe riparian zone, northern Botswana. Ph.D. Thesis, Ås: Agricultural University of Norway.

Rutina, L. P., Moe, S. R., \& Swenson, J. E. (2005). Elephant Loxodonta africana driven woodland conversion to shrubland improves dryseason browse availability for impalas Aepyceros melampus. Wildlife
Biology, 11, 207-213.

http://dx.doi.org/10.2981/0909-6396(2005)11[207:ELADWC]2.0.C $\underline{\mathrm{O} ; 2}$

Sabiiti, E. N., \& Wein, R. W. (1987). Fire and acacia seeds: A hypothesis of colonization success. Journal of Ecology, 74, 937-946. http://dx.doi.org/10.2307/2260305

Sano, J. (1997). Age and size distribution in a long-term forest dynamics. Forest Ecology Management, 92, 39-44. http://dx.doi.org/10.1016/S0378-1127(96)03958-8

Savadogo, P. (2007). Dynamics of Sudanian savanna-woodland ecosystems in response to disturbances. Doctoral Thesis, Umeå: Swedish University of Agricultural Sciences.

Savadogo, P., Tigabu, M., Sawadogo, L., \& Odén, P.-C. (2007). Woody species composition, structure and diversity of vegetation patches of a Sudanian savanna in Burkina Faso. Bois et Forêts des Tropiques, 294, 7-20.

Schultka, W., \& Cornelius, R. (1997). Vegetation structure of a heavily grazed range in northern Kenya: Tree and shrub canopy. Journal of Arid Environments, 36, 291-306.

http://dx.doi.org/10.1006/jare.1996.0208

Sekhwela, M. B. M. (2003). Woody vegetation resource changes around selected settlements along aridity gradient in the Kalahari, Botswana. Journal of Arid Environment, 54, 469-482.

http://dx.doi.org/10.1006/jare.2002.1102

Sekhwela, M. B. M., Yates, D., \& Lamb, D. (2000). Woody vegetation structure and wood availability in arid and sem-arid Kalahari sand system in Botswana. In S. Ringrose and C. Raban (Eds.), Towards Sustainable Natural Resource Management in the Kalahari Transect (pp. 65-82). Gaborone: University of Botswana.

Senbeta, F., \& Teketay, D. (2003). Diversity, community types and population structure of woody plants in Kimphee forest, a unique nature reserve in southern Ethiopia. Ethiopian Journal of Biological Sciences, 2, 169-187.

Setshogo, M. F. (2005). Preliminary checklist of the plants of Botswana. Pretoria and Gaborone: Southern African Botanical Diversity Network Report No. 37.

Setshogo, M. P., \& Venter, F. (2003). Trees of Botswana: Names and Distribution. Pretoria: Southern African Botanical Diversity Network Report No. 18.

Shackleton, C. M. (1993). Demography and dynamics of the dominant woody species in a communal and protected area of the eastern Transvaal Lowveld. South African Journal of Botany, 59, 569-574.

Skarpe, C. (1990a). Structure of the woody vegetation in disturbed and undisturbed arid savanna. Botswana. Vegetatio, 87, 11-18. http://dx.doi.org/10.1007/BF00045650

Skarpe, C. (1990b). Shrub layer dynamics under different herbivore densities in an arid savanna, Botswana. Journal of Applied Ecology, 27, 873-885. http://dx.doi.org/10.2307/2404383

Skarpe, C. (1992). Dynamics of savanna ecosystems. Journal of Vegetation Science, 3, 293-300. http://dx.doi.org/10.2307/3235754

Sokpon, N., \& Biaou, S. H. (2002). The use of diameter distributions in sustained-use management of remnant forests in Benin: Case of Bassila Forest Reserve in North Benin. Forest Ecology and Management, 161, 13-25. http://dx.doi.org/10.1016/S0378-1127(01)00488-1

Sop, T. K., Oldeland, J., Schmiedel, U., Ouedraogo, I., \& Thiombiano. A. (2011). Population structure of three woody species in four ethnic domains of the sub-sahel of Burkina Faso. Land Degradation \& Development, 22, 519-529. http://dx.doi.org/10.1002/ldr.1026

Swaine, M. D., Lieberman, D., \& Hall, J. B. (1990).Structure and dynamics of a tropical dry forest in Ghana. Vegetatio, 88, 31-51. http://dx.doi.org/10.1007/BF00032601

Tabuti, J. R. S. (2007). The uses local perceptions and ecological status of 16 woody species of Gadumire Sub-county Uganda. Biodiversity and Conservation, 16, 1901-1916. http://dx.doi.org/10.1007/s10531-006-9097-7

Tacheba, B., Segosebe, E., Vanderpost, C., \& Sebego, R. (2009). Assessing the impacts of fire on the vegetation resources that are available to the local communities of the seasonal wetlands of the Okavango, Botswana, in the context of different land uses and key government policies. African Journal of Ecology, 47, 71-77. http://dx.doi.org/10.1111/j.1365-2028.2008.01052.x 
Teketay, D. (1996b). Germination ecology of twelve indigenous and eight exotic multipurpose leguminous species from Ethiopia. Forest Ecology and Management, 80, 209-223.

http://dx.doi.org/10.1016/0378-1127(95)03616-4

Teketay, D. (1997a). Seedling populations and regeneration of woody species in dry Afromontane forests of Ethiopia. Forest Ecology and Management, 98, 149-165.

http://dx.doi.org/10.1016/S0378-1127(97)00078-9

Teketay, D. (1997b). Germination ecology of Acacia negrii, an endemic multipurpose tree from Ethiopia. Tropical Ecology, 38, 39-46.

Teketay, D. (1998). Soil seed bank at an abandoned Afromontane arable site. Feddes Repertorium, 109, 161-174.

Teketay, D. (2004-2005). Causes and consequences of dryland forest degradation in Sub-Saharan Africa. Walia, 24, 3-20.

Teketay, D. (2005a). Seed and regeneration ecology in dry Afromontane forests of Ethiopia: I. Seed production-Population structures. Tropical Ecology, 46, 29-44.

Teketay, D. (2005b). Seed and regeneration ecology in dry Afromontane forests of Ethiopia: II. Forest disturbance and succession. Tropical Ecology, 46, 45-64.

Teketay, D. (2011). Natural regeneration and management of Podocarpus falcatus (Thunb.) Mirb. in the Afromontane forests of Ethiopia. In: S. Günter, M. Weber, B. Stimm and R. Mosandi (Eds.), Silviculture in the tropics (pp. 325-336). London and New York: SpringerVerlag Berlin Heidelberg.

http://dx.doi.org/10.1007/978-3-642-19986-8_21

Teketay, D., \& Granström, A. (1995). Soil seed banks in dry Afromontane forests of Ethiopia. Journal of Vegetation Science, 6, 777786. http://dx.doi.org/10.2307/3236391

Teketay, D., \& Granström, A. (1997). Seed viability of Afromontane tree species in forest soils. Journal of Tropical Ecology, 13, 81-95. http://dx.doi.org/10.1017/S0266467400010270

Teketay. D. (1996a). Seed ecology and regeneration in dry Afromontane Forests of Ethiopia. Doctoral Thesis, Umeå: Swedish University of Agricultural Sciences.

Tesfaye, G., Teketay, D. \& Fetene, M. (2002). Regeneration of fourteen tree species in Harenna forest, southeastern Ethiopia. Flora, 197, 461-474. http://dx.doi.org/10.1078/0367-2530-1210063

Tesfaye, G., Teketay, D., Fetene, M., \& Beck, E. (2010). Regeneration of seven indigenous tree species in a dry Afromontane forest, southern Ethiopia. Flora, 205, 135-143. http://dx.doi.org/10.1016/j.flora.2008.12.006

Vanderpost, C. (2009). Molapo farming in the Okavango Delta. fact sheet 7/2009. Maun: Harry Oppenheimer Okavango Research Centre, University of Botswana.

Venter, S. M., \& Witkowski, E. T. F. (2010). Baobab (Adansonia digitata L.) density, size-class distribution and population trends be- tween four land-use types in northern Venda, South Africa. Forest Ecology and Management, 259, 294-300. http://dx.doi.org/10.1016/j.foreco.2009.10.016

West, A. G., Midgley, J. J., \& Bond, W. J. (2000). Regeneration failure and potential importance of human disturbance in a subtropical forest. Applied Vegetation Science, 3, 223-232. http://dx.doi.org/10.2307/1479001

Whelan, R. J. (2001). The ecology of fire. Cambridge: Cambridge University Press.

Wilson, B. G., \& Witkowski, E. T. F. (2003). Seed banks, bark thickness and change in age and size structure (1997-1999) of the African savanna tree, Burkea Africana. Plant Ecology, 167, 151-162. http://dx.doi.org/10.1023/A:1023999806577

Witkowski E. T. F., \& O'Connor, T. G. (1996). Topo-edaphic, floristic and physiognomic gradients of woody plants in a semi-arid African savanna woodland. Vegetatio, 124, 9-23. http://dx.doi.org/10.1007/BF00045140

Witkowski, E. T. F., \& Garner, R. D. (2000). Spatial distribution of soil seed banks of three African savanna woody species at contrasting sites. Plant Ecology, 149, 91-106. http://dx.doi.org/10.1023/A:1009850706843

Woldemariam, T., Teketay, D., Edwards S., \& Olsson, M. (2000). Woody plant and avian species diversity in a dry Afromontane forest on the central plateau of Ethiopia: Biological indicators for conservation. Ethiopian Journal of Natural Resources, 2, 255-293.

Worku, A., Teketay, D., Lemenih, M., \& Fetene, M. (2012). Diversity, regeneration status and population structure of gum and resin producing woody species in Boarana, Southern Ethiopia. Forests, Trees and Livelihoods, 1-12.

Zahabu, E. (2001). Impact of charcoal extraction to the miombo woodlands: The case of Kitulangalo area, Tanzania. Master's Thesis, Morogoro: Sokoine University of Agriculture.

Zar, J. H. (1999). Biostastical analysis (4th ed.). Upper Saddle River, NJ: Prentice Hall.

Zegeye, H., Teketay, D., \& Kelbessa, E. (2006). Diversity, regeneration status and socio-economic importance of the vegetation in the islands of Lake Ziway, south-central Ethiopia. Flora, 201, 483-498. http://dx.doi.org/10.1016/j.flora.2005.10.006

Zegeye, H., Teketay, D., \& Kelbessa, E. (2011). Diversity and regeneration status of woody species in Tara Gedam and Abebaye forests, northwestern Ethiopia. Journal of Forestry Research, 22, 315-328. http://dx.doi.org/10.1007/s11676-011-0176-6

Zida, D., Savadogo, L., Tigabu, M., Tiveau, D., \& Oden, P. C. (2007). Dynamics of sapling population in savanna woodlands of Burkina Faso subjected to grazing, early fire and selective tree cutting for a decade. Forest Ecology and Management, 243, 102-115. http://dx.doi.org/10.1016/j.foreco.2007.02.013 